\title{
"A HUNGARIAN FOR HUNGARIANS, AND NOTHING FOR MANKIND?" WILLIAM LLOYD GARRISON'S RESPONSE TO KOSSUTH'S STANCE ON SLAVERY
}

\author{
ANDRÁS TARNÓC \\ Eszterházy Károly University, Eger \\ tarnoc.andras@uni-eszterhazy.hu
}

\begin{abstract}
Following the crushing of the Hungarian Revolution and War of Independence of 1848-1849 Lajos Kossuth was forced into exile in Turkey. Thanks to intervention on behalf of the American government that he was able to travel to the United States in 1851-52. His visit left a lasting mark on American culture. He made over 500 speeches and public appearances, however his position on slavery led to a controversy eventually undermining his original purpose of securing American support for the potential renewal of the Hungarians' struggle for freedom.

While anti-slavery activists in the United States, especially William Lloyd Garrison, were looking forward to him openly supporting the abolitionist cause, Kossuth opted for a much-maligned policy of non-interference. In response, Garrison, while admiring Kossuth at first, changed his stance and launched a vitriolic attack in a book-sized publication titled Letter to Louis Kossuth Concerning Freedom and Slavery in the United States (1852).

While the circumstances of Kossuth's visit have been a subject of numerous scholarly essays, I intend to focus on Garrison's text in the forthcoming analysis of its form and content.
\end{abstract}

Keywords: antebellum slave narrative, indirect slave narrative, abolition, Monroe Doctrine, fallacy.

Following the crushing of the Hungarian Revolution and War of Independence of 1848-1849 Lajos Kossuth, erstwhile Governor-Regent of Hungary, was forced into exile in Turkey. It was due to intervention on behalf of the American government that he was able to travel to England and the United States in 1851-52. His visit was a remarkable episode of Hungarian-American relations and left a lasting mark on American culture, while also gaining the sympathy of the American people for the Hungarian cause. According to Gyula Szekfü "Kossuth alone did more for the popularization of Hungary, and arousing sympathy for the Hungarians, than all the efforts of all the successive generations since" (Vardy). ${ }^{1}$ 
Although Kossuth undoubtedly caught the imagination of Americans everywhere, his trip did not produce tangible results. He made over 500 speeches and public appearances, however his position on slavery led to a controversy eventually undermining his original purpose of securing American support for the potential renewal of the Hungarians' struggle for freedom.

Since he had gained international fame as a hero of universal freedom, anti-slavery activists in the United States, especially the well-known firebrand, William Lloyd Garrison, were looking forward to him openly supporting the abolitionist cause. Kossuth, however, aiming to avoid being caught up in the slavery quagmire, opted for a much-maligned policy of non-interference. Thus Garrison, while admiring Kossuth at first, changed his stance and launched a vitriolic attack in a book-sized publication titled Letter to Louis Kossuth Concerning Freedom and Slavery in the United States (1852). While the circumstances and the impact of Kossuth's visit have been a subject of numerous scholarly essays including the works of Steven B. Vardy, István K. Vida, Tibor Frank, and Csaba Lévai, I intend to focus on Garrison's text in the forthcoming analysis of its form and content.

\section{II}

As Jim Powell argues, in the end of the $18^{\text {th }}$ century it seemed that Garrison's future cause would become moot. Starting with Vermont in 1777 and concluding with the Northwest Ordinance of 1787, slavery was eliminated in the North. Two events, however, the invention of the cotton gin in 1795 and the Louisiana Purchase of 1803, gave it additional momentum. Eventually two views emerged regarding the peculiar institution, one favoring gradual emancipation and repatriation to Africa, the other envisioning colonization, boosted by the English establishing Sierra Leone and the founding of Liberia with the help of the American Colonization Society. While at first Garrison supported colonization, driven by a missionary zeal he started to demand immediate emancipation. In 1831, with his associate Benjamin Lundy, he founded the Liberator, which became the mouthpiece of the abolition movement. His uncompromising stance is demonstrated by this often quoted statement: "On this issue I shall not equivocate: will be as harsh as truth, and as un-compromising as justice. On this subject, I do not wish to think, or speak, or write, with moderation. $-I$ will not excuse $-I$ will not retreat a single inch - AND I WILL BE HEARD."”

In the light of the above, his response to Kossuth is not surprising or unexpected. Kossuth's trip took place during one of the most turbulent periods of American history, while he was faced with the question of slavery, primarily brought on by the recent territorial expansion driven by the 'Manifest Destiny' belief. Kossuth hoped to bolster his own cause by establishing connection with 
the Young America movement, an aggressive expansionist political faction aiming to change the country's traditionally isolationist foreign policy warranted by Washington's "Farewell Address" (1796) and the Monroe Doctrine (1823).

While Kossuth to a certain extent enjoyed the support of the Young America movement, especially of senators Lewis Cass from Michigan and Pierre Soulé from Louisiana, politicians of the Washington mainstream including President Millard Fillmore did not wholeheartedly welcome his efforts. Although Henry Clay, known as the leading politician of the period, expressed his admiration for Kossuth and his cause, he rejected Kossuth's push for American interference in favor of Hungary in no uncertain terms: "I entertain the liveliest sympathies for every struggle for liberty in Hungary [...] But sir, for the sake of my country, you must allow me to protest against the policy you propose to her." ${ }^{\text {"3 }}$ It is only ironic that Kossuth declared his own policy of non-interference concerning slavery and he was confronted with the same official approach regarding his own political quest.

Kossuth, attempting to gain the sympathy of the American people for his cause, presented himself in his speeches both as a private citizen and as a public hero. His self-portrayal as a "poor, persecuted, penniless exile,"" or a "wandering son of a bleeding nation" is complemented by comments and observations made about the political system and the international or geopolitical role of the United States. Yet his statement made in New York on December 12, 1851: "every nation has the sovereign right to dispose of its own domestic affairs, without foreign interference; that $\mathrm{I}$, therefore shall not meddle with any domestic concerns of the United States"5 drew heavy criticism from abolitionists, especially Garrison.

Kossuth in his description of the United States employs such terms as "glorious shores," "soil of freedom," an "asylum for the oppressed," "and refers to his hosts as true representatives of American principles and generosity, ${ }^{9}$ while describing the country as a protector of human rights. ${ }^{10}$ In line with Alexis de Tocqueville and Lord Bryce, yet lacking their objectivity, he recognizes the main aspects of the American ideal expressed in the core values of freedom, democracy, individualism, and equality. Kossuth finds solace in the fact that "the United States are resolved not to allow the despots of the world to trample on oppressed humanity." he never expressed his intention, or entertained the thought of asking for political asylum in the United States, by referring to himself as "a poor, persecuted, penniless exile, and the son of a bleeding nation"12 he casts himself in the role of the typical immigrant drawn to the U.S. by economic opportunities and political freedom.

$\mathrm{He}$ also uses the example of the Mexican-American war, denoting it as a "glorious struggle" 13 to justify the legitimacy of his own position. This is, however, an erroneous argument, as it was the United States which had provoked the war, despite being a "morning star of rising liberty,"14

His description of the United States amounts to a reiteration of American exceptionalism. Kossuth's insufficient knowledge of the international status quo 
is his weakness. His proclaimed attitude of non-interference on the one hand belies his assumed private citizen status, while on the other, his hoping that the United States would interfere in European politics on behalf of Hungary betrays his lack of familiarity with the Monroe doctrine. Moreover, praising the Mexican-American War as a "glorious struggle" amounts to a misunderstanding of the contemporary geopolitical reality at best. Accordingly, no comparison can be made between the Hungarian freedom fights and the Mexican-American conflict, as the latter was basically a colonial war provoked by the US for territorial gain. In the same vein, drawing a parallel between the literal exile of the Hungarian government and potential relinquishing of the American presidency as a result of Mexico overrunning the United States and placing Mexico in the role of Austria is also erroneous since in the Mexican war the United States was the aggressor, or, by extension, it acted as Austria did in Hungary.

Kossuth attempts to appeal to America's self-image as the exceptional nation, or ride the crest of the wave of American patriotism to gain sympathy for his cause. Vacillating between the positions of private citizen and revered statesman betrays a weakness and inconsistency which Garrison immediately exploits.

Garrison's main argument or message can be summed up in one sentence. Kossuth's admiration of the United States as the ideal manifestation of Western democracy implied the covert acceptance of slavery. Garrison is convinced that Kossuth's non-interference policy automatically qualifies as a recognition of the peculiar institution. He believes that Kossuth as a champion of liberty has a duty to fight for all the downtrodden, mainly blacks, but he mentions Native Americans, as well.

Garrison's accusation of Kossuth sacrificing the lofty cause of human freedom on the altar of realpolitik is supported by a host of evidence including speeches and statements from leading abolitionists worldwide. He counters Kossuth's eloquent rhetoric reflecting American super-patriotism and national pride with a stark question: "To declare, over and over again, 'I never did or will do anything which in the remotest way could interfere with the matter alluded to' [slavery] - is not this to the bidding of the slave power in the most effectual manner?"15

Garrison's main premise is that by declaring a policy of non-interference regarding slavery Kossuth betrayed or abandoned the cause of universal freedom, the idea he had originally come to represent. His favored technique is juxtaposing Kossuth's speeches with the American reality.

Viewed from the standpoint of logic the Letter can be summed up as a syllogism:

1. Slavery is a universal sin.

2. Any person representing a struggle for freedom should raise his voice against it.

Conclusion: Kossuth's reluctance to address the issue makes him an accomplice in this universal sin. 
While Garrison's Letter reflects an overall commitment to the liberation of mankind, his response to Kossuth, better yet, his reaction to Kossuth (as the latter never directly addressed the former) is replete with the customary logical errors and fallacies characteristic of texts serving propaganda purposes. While Garrison meticulously builds up his case, citing English, Irish, and French sources, his zeal leads him astray and his anti-Kossuth tirade abounds in ad hominem attacks and instances of the slippery slope and the false choice. Although he attempts to refute Kossuth's statements virtually sentence by sentence, and uses various testimonies of leading international public figures including Daniel O'Connell, his main argument is based on the repetition of a rather ambiguous numerical expression, namely that every $6^{\text {th }}$ person in the United States was forced into slavery or lived in bondage.

Going further, these logical shortcomings are encased in hyperbolic language. Consequently, it is noteworthy that Garrison thinks in extremes, cannot envision any middle ground and automatically assumes that Kossuth's policy of non-interference amounts to a covert support of slavery. In this vein, one could ask, why did Garrison assign to Kossuth an automatic responsibility for speaking up on the issue of slavery? He deems Kossuth's approach of "seeking aid for Hungary a cowardly and criminal policy" ${ }^{16}$ and in an effort to slander Kossuth he often uses the term "recreant."

While Kossuth praises America as a haven for the wretched, Garrison sees "a nation of slave-catchers and human flesh-mongers" ${ }^{17}$ and for him the "soil of freedom" is ruled by a "slave-breeding and slave hunting government." ${ }^{18}$ Garrison recruits Daniel O'Connell, the Irish patriot to his cause and juxtaposes his position to Kossuth's non-interference: "I pronounce every man a faithless miscreant who does not take a part in the abolition of slavery." ${ }^{19}$ Garrison at the same time places Kossuth in the position of the exotic, that is the Other, by referring to his speeches as "charged with the electric flame of oriental eloquence." ${ }^{20} \mathrm{He}$ considers slavery a "stain on the national escutcheon" ${ }^{21}$ and refers to slaves as "millions of fellow creatures in chain."22 In Garrison's view Kossuth shirked his general Christian responsibility, acting as a "Hungarian for Hungarians, and doing nothing for mankind," and just like Cain, he abandoned his duty as "his brother's keeper" (Genesis 4:9). ${ }^{23}$

I intend to show that Garrison's response to Kossuth displays the main features of the slave narrative and in fact can be considered its indirect version. As Ira Berlin argues, the genre of the slave narrative includes more than former slaves recalling their ordeals and their subsequent escape from bondage. Consequently, the descriptions of the circumstances of slavery can take an indirect form either written by a slaveholder or a representative of mainstream society. Examples of such texts are produced by Alonso Sandoval, the Spanish missionary describing the lives of slaves arriving in Cartagena at the beginning of the $17^{\text {th }}$ century in De 
Instauranda Aethiopium Salute (1627), or John Gabriel Stedman commemorating his experiences while fighting against a slave uprising in Narrative of a Five Year's Expedition amongst the Revolted Negroes of Surinam (1796).

John Olney identified formal and content-based components shared by slave narratives. The ubiquitous term "I was born" at the beginning of such texts refutes the chattel status of the slave and at the same time asserts his or her humanity. The narratives provide detailed information about the respective ordeals and the logistics of slavery, including the duties the slave performed and the description of the slave auction. ${ }^{24}$ Both Houston Baker and Henry Louis Gates emphasize the significance of the writing process as a catalyst to achieving subject status from an objectified and muted existence. Baker sees writing as a demonstration of the slave's status as a human being, while Gates points out that acquiring literacy for the slave did not primarily mean the "mastery of letters, but a membership in the human community." 25

The antebellum slave narratives aimed to evoke the sympathy of the reader by commemorating the slave's struggle for freedom. The gruesome details of the given ordeal were coupled with an ambiguous view of religion. While according to John Barbour religion was one of the defining tropes of such texts and helped the expression of individual will and the promotion of psychological healing, ${ }^{26}$ several former slaves, among them David George and Frederick Douglass, voiced passionate criticism of Christianity. Douglass referring to the "reverend - slave driver, Rigby Hopkins" asserts that nothing is worse than a religious master ${ }^{27}$ and George describes his ordeal suffered at the hands of a Protestant master.

Earlier forms of the slave narrative, especially the ones written in the second half of the $18^{\text {th }}$ century, functioned as documents recording the process of spiritual growth and they primarily raised their voice against the slave trade. Yet, even the best known author of such texts, Olaudah Equiano himself turned slave trader. At the same rate the second generation of slave narratives, i.e. those produced in the first half of the $19^{\text {th }}$ century, mainly after the prohibition of the import of slaves to America and Britain's abolition of involuntary servitude went into effect in 1807 and 1833, principally served abolitionist objectives as a genre.

Garrison opposes slavery on spiritual, humanitarian, and egalitarian grounds. In order to evoke the sympathy of the reader he resorts to ploys known from sentimental literature. Thus, in addition to presenting the graphic details of the slave's ordeal, he assigns the slave-holder or planter into the role of the villain or rake, a staple of sentimental literature.

In the form of an indirect slave narrative Garrison provides a detailed description of the fate of one of Henry Clay's slaves. The choice of the master is not merely incidental as the revered legislator from Kentucky represented the very slave-holding government Garrison so despised, and Clay played a part in the joint resolution authorizing President Fillmore to send the USS Mississippi to transport Kossuth and his entourage from their exile in Kütahya to America. ${ }^{28}$ 
Furthermore, Clay was the president of the American Colonization Society promoting the gradual emancipation and repatriation of manumitted slaves to Africa. Garrison considers slavery as a curse and spares no detail in informing the reader of the psychologically and physically devastating effect of the slave market:

Every man knows that slavery is a curse. Whoever denies this, his lips libel his heart. Try him! Clank the chains in his ears, and tell him they are for him ; or give him an hour to prepare his wife and children for a life in slavery ; bid him make haste, and get ready their necks for the yoke, and their wrists for the coffle chains : then look at his pale lips and trembling knees and you have nature's testimony against slavery. ${ }^{29}$

In order to refute Clay's claim that his slaves are "well fed and clad" and "they look sleek and hearty," 30 Garrison reports on the ordeal of the former's slave Lewis Richardson. Accordingly, Richardson, failing to report from a furlough was severely punished. After the overseer hit him in the head with a handspike, he turned to his owner, but Clay refused to hear his pleas and had his slave severely whipped and left to die in the freezing December cold. After recovering, Richardson escaped from the plantation and eventually reached Canada.

Despite its relative brevity the story calls for further analysis. Garrison's account of Richardson's ordeal displays the cyclical components of the antebellum slave narrative retracing the protagonist's progress from muted object to a subject possessing agency and the power of expression. Depending on the geographic origin of the slavery experience the slave narratives have varying plot elements. Accordingly, the accounts of first generation slaves can be divided into such stages as separation, objectification, integration into the social structure of slavery and obtaining the subject status. Separation implies being captured in Africa, the objectification stage primarily taking place during the Middle Passage includes the ordeal, the accommodation, and the acceptance. In this case the captured African suffers a symbolic death and turns into a commodity. While the integration stage on the one hand includes inscription into a secondary position within the social and economic structure of the plantation, it can launch the subjectivation phase culminating in the achievement of subject status via contemplating and eventually making the decision to escape. In case of the narratives of second or third generation slaves the plot is significantly shortened as the individual is born into a system of slavery. Nevertheless, the symbolic death stage, usually brought about by a cruel punishment which the slave is forced to endure, tends to motivate him or her to achieve subject status via the cycles of determination, escape, and reintegration. Since Richardson had been "wearing the galling chains on his limbs 53 years," ${ }^{31}$ and the actual ordeal took place in 1845 , it can be safely 
surmised that he was brought to America from Africa before the importation of slaves became illegal in 1807 .

The beating itself steels Richardson's resolve to break out of chattel status, and while recovering from his injuries and partly urged on by his wife he decides to escape, and by the help of Him, "who tempers the winds to the shorn lamb" (Psalm 6:2) ${ }^{32}$ flees to Canada. Since he is in a new country, reintegration gives way to integration, that is, to fitting into a new social structure,

The account also reveals the main autobiographical components identified by Barbour. Individualism is present in references or in an indirect form. As Zsolt Virágos asserts, the slave narrative is a prototype of the American success story, with the slave functioning as the early version of the self-made man. The emergence from object status to that of the subject with the power of expression and agency is indicated by the slave's decision to escape. While in general the escaped slaves had several helpers, including the Underground Railroad, he or she definitely achieved the power to control their fate. This progress from helpless object to a subject who is conscious and self-aware is clearly retraced in the respective section of Garrison's text.

Despite such a significant individual achievement Garrison locates the slave in the context of the universal abolition movement, which is primarily led by white activists. Our case in point is Richardson himself, who escapes but leaves the American, i.e. US, mainstream and is integrated into Canadian society. "Fleeing from the American eagle and taking shelter under the British Crown," ${ }^{33}$ functions as the condemnation of American society both in the domestic and the international arena. Garrison in his Preface to Douglass' Narrative reinforced in a condescending way the white interest in the leadership of the abolition movement as he referred to Douglass as "capable of high attainments as an intellectual and moral being - needing nothing but a comparatively small amount of cultivation to make him an ornament to society and a blessing to his race." ${ }^{34}$

Healing refers to curing the illness of American society, the curse of slavery. Garrison's primary objection to slavery is its violation of the basic principles of Christianity - as Lauter asserts "to be a Christian was, for Garrison, to carry out literally the injunctions of the Sermon on the Mount." ${ }^{35}$ The urgency of Garrison's response to Kossuth is justified by the hostile attitudes he witnessed regarding this issue in New England, where he found "contempt more bitter, opposition more active, detraction more relentless, prejudice more stubborn, and apathy more frozen, than among slave-owners themselves." 36

In general, slave narratives contain only sporadic references to race, as their target audience was not the black community, but the white mainstream reader. Consequently, the author, just like Garrison, places the slave in the context of universal humanity. In his Letter Garrison, partly driven by a need to avoid antagonizing his potential readers, does not emphasize racial markers, and references 
to skin color are not prevalent. The slaves are mostly referred to as Negro, or "people of African origin", thereby emphasizing social and cultural status instead of falling into the trap of unwittingly 'othering' the slaves, thereby increasing the distance between them and the mainstream.

\section{III}

The sheer fact that a significant figure of contemporary American society dedicated a substantially researched text to counteract or cast doubt on almost every aspect of Kossuth's speeches indicates the public stature which Hungary's greatest national hero had attained across the western world. Garrison not only located the original versions of Kossuth's speeches made in America, but contrasted the Governor-Regent's statements with the facts related to slavery.

Similarly to Garrison, Karl Marx also criticized Kossuth for his inconsistency and impulsive political behavior:

It will be admitted by the most prejudiced admirers of Mr. Kossuth that, whatever his other accomplishments may be, he has always sadly lacked one great quality - that of consistency. During the whole course of his life he has more resembled the improvisatore receiving his impressions from his audience than the author imprinting his own original ideas upon the world. This inconsistency of thought could not but reflect itself in duplicity of action. ${ }^{37}$

In sum it may be concluded that the success of Kossuth's trip was undermined by Garrison's attacks. Garrison and Kossuth's encounter was the meeting of two firebrands, radical thinkers and historical actors. Both of them struggled for a worthy goal, the former aimed at the elimination of human bondage, the latter for the freedom of his country. Garrison chiding Kossuth for neglecting the issue of slavery was driven by a romantic egalitarianism, while Kossuth, fighting for a similarly worthy cause, became involved in controversial situations, which, partly due to his lack of experience in the international arena, he couldn't handle effectively. The two men, a radical reformer and an exiled former leader, did not officially represent their countries, moreover no meeting took place between them. Both applied to the conscience of mankind in the name of enslaved persons and a virtually enslaved country respectively. Garrison and Kossuth were equally passionate reformers and rejected gradualism concerning the elimination both of slavery and of the Hapsburg control of Hungary. Furthermore, both imperson- 
ated their cause, as Garrison spoke on behalf of the whipped slave and Kossuth spoke up for his bleeding country. Although it is beyond doubt that the two men sometimes committed serious errors, their inconsistencies cannot diminish their contribution to the respective causes they fought for.

\section{References}

Baker, Houston A. Jr. The Journey Back: Issues in Black Literature and Criticism. Chicago: The University of Chicago Press, 1980.

Clay, Henry. The Papers of Henry Clay Candidate, Compromiser, Elder Statesman edited by Melba Porter Hay, Vol. 10. January 11844 - June 29 1852. The University Press of Kentucky, 1991.

Douglass, Frederick. "Narrative of the Life of Frederick Douglass, an American Slave." In The Heath Anthology of American Literature. edited by Paul Lauter, 1640-1704. D. C. Heath, 1990.

Garrison, William Lloyd. Letter to Louis Kossuth Concerning Freedom and Slavery in the United States. Boston: R. F. Walcutt, 1852.

---. "The Story of His Life." In The Heath Anthology of American Literature. edited by Paul Lauter, 1794-1795. D. C. Heath, 1990.

Gates, Henry Louis, Jr. The Signifying Monkey: A Theory of African-American Literary Criticism. New York: Oxford University Press, 1988.

Juster, Susan et al., "Forum: Religion and Autobiographical Writing," Religion and American Culture: A Journal of Interpretation. 9, no. 1, (1999): 1.

Lauter, Paul. "William Lloyd Garrison" In The Heath Anthology of American Literature. edited by Paul Lauter, 1792-1793. D. C. Heath, 1990.

Marx, Karl. "Kossuth and Louis Napoleon." http://marxengels.public-archive.net/en/ME1169en. html

Olney, John. "I was born:' Slave Narratives, Their Status as Autobiography and as Literature.” In The Slave's Narrative. edited by Charles T. Davis and Henry Louis Gates Jr. 148-174. New York: Oxford University Press, 1985.

Powell, Jim. “The Sin of Slavery.' A Biography of William Lloyd Garrison” https://www.libertarianism.org/publications/essays/sin-slavery-biography-william-lloyd-garrison

Várdy, Steven B. "Kossuth's Effort to Enlist America into the Hungarian Cause.” Hungarian Studies 16, no. 2 (2002): 237-252. http://www.epa.hu/01400/01462/00028/pdf/237-252.pdf

Vida, István, Kornél. "A nemzet nem szívesen látott vendége? Kossuth ellenesség az Egyesült Államokban 1851-1852." [The Unwelcome Guest of the Nation. Anti-Kossuth Sentiment in the United States] Aetas 29, no. 2 (2014): 67-86.

\section{Notes}

1 Steven B. Várdy, "Kossuth's Effort to Enlist America into the Hungarian Cause." Hungarian Studies 16/2 (2002): 237-252. http://www.epa.hu/01400/01462/00028/pdf/237-252.pdf

2 https://www.harvardsquarelibrary.org/biographies/william-lloyd-garrison/

3 Henry Clay, The Papers of Henry Clay Candidate, Compromiser, Elder Statesman edited by Melba Porter Hay. Vol. 10 January 11844 - June 29, 1852. The University Press of Kentucky, (1991): 944.

4 William Lloyd Garrison, Letter to Louis Kossuth Concerning Freedom and Slavery in the United States. Boston: R. F. Walcutt, 18526. 
5 Ibid 81

6 Ibid 13

7 Ibid 59

8 Ibid 17

9 Ibid 11

10 Ibid 60

11 Ibid 56

12 Ibid 4

13 Ibid 10

14 Ibid 12

15 Ibid 60

16 Ibid 8

17 Ibid 17

18 Ibid 60

19 Ibid 43

20 Ibid 5

21 Ibid 5

22 Ibid 6

23 Ibid 8

24 John Olney, "I was born:' Slave Narratives, Their Status as Autobiography and as Literature." The Slave's Narrative edited by Charles T. Davis and Henry Louis Gates Jr. (New York: Oxford University Press, 1985), 152-153.

25 Henry Louis Gates Jr., The Signifying Monkey: A Theory of African-American Literary Criticism. (New York: Oxford University Press, 1988), 128.

26 Susan Juster et al, "Forum: Religion and Autobiographical Writing," Religion and American Culture: A Journal of Interpretation. 9/1, (1999):1.

27 Frederick Douglass, "Narrative of the Life of Frederick Douglass, an American Slave." The Heath Anthology of American Literature. edited by Paul Lauter, (D. C. Heath, 1990). 1682.

28 Vida, István, Kornél. "A nemzet nem szívesen látott vendége? Kossuth ellenesség az Egyesült Államokban 1851-1852.” Aetas 29, no. 2, (2014): 70.

29 William Lloyd Garrison. Letter to Louis Kossuth Concerning Freedom and Slavery in the United States. (Boston: R. F. Walcutt, 1852)

30 Ibid 70

31 Ibid 72

32 Ibid 71

33 Ibid 72

34 Frederick Douglass, "Narrative of the Life of Frederick Douglass, an American Slave." The Heath Anthology of American Literature. edited by Paul Lauter, (D. C. Heath, 1990). 1641.

35 Paul Lauter. "William Lloyd Garrison" The Heath Anthology of American Literature. edited by Paul Lauter, (D. C. Heath, 1990), 1793.

36 Ibid 1794

37 Karl Marx. "Kossuth and Louis Napoleon.” http://marxengels.public-archive.net/en/ME1169en. $\mathrm{html}$

Open Access. This is an open-access article distributed under the terms of the Creative Commons Attribution 4.0 International License (https://creativecommons.org/licenses/by/4.0), which permits unrestricted use, distribution, and reproduction in any medium, provided the original author and source are credited, a link to the CC License is provided, and changes - if any - are indicated. (SID_1) 
